\title{
ENVIRONMENTAL REFUGEES IN SUB-SAHARAN AFRICA Causes and Effects
}

\author{
Ogenga Otunnu
}

Environmental degradation, overpopulation, droughts, famines, debt crisis, political and social instability, and economic marginalization have become popular catchwords in any major debate on Africa. One of the most tragic indicators of the continent's chronic state of demise is the extremely high incidence of refugees. Although sub-Saharan Africa only has about ten percent of the world's population, it accounts for nearly twenty-five percent of the world's refugees (Lofchie: 89 ). A substantial percentage of these were environmental refugees, "people fleeing land that could no longer support them" (Timberlake: 162). Others have fled civil wars and human rights violations. There are millions more internally displaced people who are not legally recognized under international law as refugees. Unless there is a major reversal of current trends, there is very little basis for optimism about the famine or the economic, environmental and refugee crises in Africa. In retrospect, debate about the complex and controversial concept of an environmental refugee in sub-Saharan Africa must be located in and informed by the larger discussion on the crisis facing the entire region. Various factors that directly or indirectly lead to environmental deterioration or degradation include: desertification, deforestation, drought, land degradation and depletion, locusts, wars, deterioration of the ozone layer, overpopulation and flooding. It should be indicated straightaway that there are no impenetrable walls between environmental, political and economic factors - they are, at one and the same time, causes and effects of environmental crisis.

Ogenga Otunnu is a Doctoral Candidate in the Department of History at York University and a Researcher in the Centre for Refugee Studies.
This paper is devoted to a general description of environmental degradation in sub-Saharan Africa and to a review of the factors that play a significant role in causing environmental refugees. It is hoped that the following points will be highlighted: that the concept of an environmental refugee is a multi-dimensional phenomenon. It has exogenous and endogenous aspects, causes and effects. While climatic change has compounded the crisis, the nature of the state, the political economy of subSaharan Africa, and the international economic system are largely responsible

\section{"In retrospect, debate about the complex and \\ controversial concept of an environmental refugee in sub-Saharan Africa must be located in and informed by the larger discussion on the crisis facing the entire region."}

for generating environmental refugees. Environmental catastrophes have far more devastating impacts on the poor, the young, and therefore the most vulnerable groups in their societies. Put succinctly, impacts differ depending on gender, age, class and region. Finally, environmental degradation exacerbates the crisis of underdevelopment, political instability and refugee problems in the region.

\section{Natural Causes}

The severe droughts of the 1970 s and 1980 s not only initiated new environmental and land quality problems as well as exposing and accelerated existing ones, they also focused attention on the underlying weaknesses in the economic and agricultural systems of the sub-Saharan region. Compounded by the economic vulnerability of the sub-continent, the droughts led to devastating famines displacing millions and sending many more fleeing their lands. Scholars, including S.E. Nicholson (1985), Nicholson and D. Entekhabi (1986), C.A. Wood (1977), D.J. Shove (1977), Eugene M. Rasmusson (1987) and Workineh Degufu (1987), point out that there is a major ecological change affecting the region. In his work on Ethiopia, Degefu indicates that due to the 1980 s drought, thousands of domestic and wild animals perished, forest fires caused incalculable damage to the forest-based economy, and large population migrations took place from the arid north to the west and southwest direction. Dessalegn Rahmato (1991) adds:

As of December 1987, over two million
peasants in Tigrai and Wollo were said to
be in distress and in need of emergency
assistance. In the early part of the year, the
northeast and Eritrea were threatened by a
serious locust invasion, said to be the worst
outbreak since 1958... The outlook for
1988, according to Relief and Re-
habilitation Commission, was quite
gloomy: more than 5.2 million peasants in
the country were expected to starve if relief
supplies did not reach them in time. The
worst affected areas were Eritrea, Tigrai
and northern Wollo, but peasants in North
Shoa, northeastern Gondar, and parts of
Harrarghe provinces were also suffering
from drought and food shortages. In many
areas in the northern provinces the $1987 /$
88 harvest failed completely, and peasants
were faced with starvation on a large scale.
(14-15)

As Hailu Lemma (1985), PeterLawrence, Francis Snyder and Moris Szefte (1985) correctly point out, the situation was compounded by the wars in Eritrea and Tigray. 
Wars

Wars are rampant in Africa. In Mozambique, Frente de Libertação de Mozambique (FRELIMO) has been engaged in a long and costly war with the Mozambique National Resistance and its ally, the government of South Africa. In Angola, war continues between the Movimento pela libertação de Angola (MPLA)a government and the dissident União Nacional para a Independencia Total de Angola (UNITA). In the Sudan, the government in Khartoum has been fighting against

\section{"Wars make sustainable land use and agricultural development impossible. Furthermore, a regime that is militarily engaged in battles for its survival places no priority on sustainable environmental practices."}

the Sudan People's Liberation Movement. In Chad, wars, and annexation of the extreme north by Libya led to a temporary semi-partitioning of the country. Uganda has witnessed several wars: $1978-79$ between Uganda and Tanzania, 1980-85 in the Luwero Triangle and West Nile, and since 1985 in the Northern and Eastern regions. There is a close connection between wars and environmental degradation, refugees, famine and economic crisis. Wars make sustainable land use and agricultural development impossible. Furthermore, a regime that is militarily engaged in battles for its survival places no priority on sustainable environmental practices. Wars rule out care for the environment. Also, desertification may be caused by "activities of shells, bombs and tracked vehicles." Timberlake is convincing when he concludes that: "War damages the environment; but environmental degradation can also add to the pressure from which conflict emerges" (165).

\section{Overpopulation and Other Human Activitles}

Environmental degradation is not only caused by climatic change in the region. In retrospect, MichaelH. Glantz explains this phenomenon in terms of population explosion and other human activities:

In the 1960s, when the West African Sahel was enjoying a moist climate, a number of communities were established in areas previously regarded as inadequate to sustain agriculture. Everincreasing human and animal populations have threatened traditional agricultural and livestock-raising practices. Overcultivation and over-grazing have reduced the productivity of land. The widespread destruction of tree cover for fuelwood (encouraged by high prices of petroleumbased fuel) and construction has accelerated the degradation. Poor water management and the salinization of irrigation systems have also left their mark. The net result is that each year 1.5 million hectares are overwhelmed by a glacier of sand. $(\mathrm{xv})$

This and other related factors, which have led to nearly two decades of the harshest drought in recent history

have had a devastating effect upon the people and the economic and social systems of a score of African countries. It has wrenched the ecology and the environment of most of the continent. Successive failures have led to food scarcity, resulting in malnutrition, unchecked disease, the decimation of livestock herds and ultimately famine, with staggering loss of human life. There has been enormous migration - within and between countries - and human suffering... In addition, the drought has aggravated the economic crisis that almost all subSaharan countries have been experiencing. It has further depleted government revenues and foreign exchange, intensified unemployment and brought growth in major productive centres to a halt. (xvi-xvii)

Glantz traces the root causes of the crisis to what he calls "colonial baggage" and the subsequent integration of the region into the international capitalist economy. In his view, African economies are highly dependent on marketeconomies and keyed to the export of commodities, which has precipitated the neglect of food-production systems. He asserts that environmental degradation and overpopulation largely reflect the failures of national decision-making in the region. In keeping with the general thrust of his argument, Glantz maintains that drought leads to famine in Africa because of the vulnerability of the society. Put succinctly, "the real problem in Africa is poverty." Like Robert J. Cummings (1987), he concludes that there is a close link between environmental degradation, drought, famine, national policies, the International economic system and economic (under)development.

Glantz and his colleagues are not alone in their assertions. As a matter of fact, whenever a major environmental catastrophe occurs in sub-Saharan Africa, discussions centre around overpopulation, deforestation, soil erosion, crop failures and misuse of land. In arid and semi-arid areas, discussions on environmental degradation focus on desertification, a catch-all term that encompasses soil erosion due to wind

"African economies are
highly dependent on market-
economies and keyed to the
export of commodities, which
has precipitated the neglect
of food-production systems."

and water, soil compaction due to trampling, firewood gathering, reduced follow time salinization and waterlogging (Glantz: 49; A. Warren and J.K. Maizels, 1977: 1). But why does overpopulation persist? And to use Mahmood Mamdani's words (1985), why do people cut down forests? Why do they overgraze? Why do they work the same tired land without resting it? Is it out of sheer ignorance?

There is no single uncontested answer to each question raised. Nonetheless, most literature on development in Africa suggests that high 
population growth is a result of inadequate education on the relevant issue. In retrospect, by indicating that the young and most vulnerable comprise the majority of the population, national governments are urged to put in place coherentandinformed policies to control high population growth. Education is often emphasized as central to overcoming the problem. Similarly, deforestation and land degradation are often linked to overpopulation, ignorance and poor agricultural and land-use policies. Governments, donors and intellectuals have blamed nomadism for problems arising due to overgrazing (E.H. Palmer, 1974: 297-300; M.J. Herskovits: 1926; G.P. Murdock, 1959; A. Lomax and C.M. Arensberg, 1977:659-701).H.F. Lamprey asserts that overwhelming evidence indicates that overgrazing is the cause of "widespread damage to semi-arid and arid zone grasslands" (1983: 643-66). The FAO has attacked the very character of pastoralists: "... caring for nothing, disdaining manual labor, balking at paying taxes, and being unwilling to sell their animals...; they do not make the economic contribution to their countries that is rightfully expected of them" (1973: 14). In its later work the Food and Agriculture Organization (FAO) finds the cause of environmental degradation in the attitudes and customs of pastoralists, not the conditions under which pastoralism operates. "It is basically a problem of the misuse of land... particularly in pastoral areas, much of the problem results from the customs, value systems and attitudes of the people concerning grazing lands and livestock, together with the lack of government mechanisms for effective control" (1980: 56; for a comprehensive review of the literature, see Michael M. Horowitz and Peter D. Little (1987)). Such a view, which favours sedentarization, does not only lead to greater impoverishment of the pastoralists, it has negative environmental and productive impacts.

An explanation for environmental degradation and environmental refugees which reduces the causes and persistence of the crisis to individuals and fails to understand the conditions under which the crisis occurs, is a false comfort since it cannot lead to appropriate actions. In his contribution to the debate, Mamdani like Timothy Shaw (1987) is convinced that the genesis of the disaster is to be found in the colonial political economy which led to the peripheralization and marginalization of the peasants. Like Walter Rodney (1972), Martin Klein (1980), Shula Marks

\section{"For these changes to be explored, there is an urgent need to develop viable civil institutions that can effectively articulate and meet the socio-economic and political demands of the people."}

(1985), Jane I. Guyer (1980), Robin Cohen (1976), Jane L. Parpart (1983), and R.H. Bates (1989), he asserts that colonial land, labour and taxation policies led to both exploitation and pronounced disparities. This system, he goes on, which favours cash crops at the expense of food crops, big traders (including the state) at the expense of small peasants and pastoralists in rural areas, has remained essentially unchanged in neo-colonial sub-Saharan Africa. It is in response to the crisis that a peasant or a pastoralist uses whatever control he or she has over land and labour. With land scarcity, the peasant is forced to work the tired land over and over. In keeping with the focus of his work on Uganda, Mandani writes:

At the same time, the peasant has as many children as possible to maximise the labour at his disposal. For a middle-class family, a child may be just a mouth to feed for 20 years, but for a peasant family after four years the child is also two hands to work! My point is that people are not poor because they have large families; really they have large families because they are poor! ... Of course, each of the solutions arrived at by the peasant is contradictory. It solves the problem in the short run, only to reproduce it much worse in the long run: on the one hand soil erosion, on the other, 'overpopulation.'The sharpest expression of this is Karamoja ... The Karamoja famine can't be fully understood without an historical analysis. Its starting point must be understood that the Karamojong people lost roughly 20 per cent of their grazing land, in phases, through either the redrawing of administrative boundaries in the 1920s or creation of National Park like Kidepo later. It is this fact which called forth a change in pastoral practices. No longer could grasslands be rested up to the annual burning. Not only was all grazing land used throughout the years without any annual burning, forests were progressively cut down to increase the grazing area. (95)

In a similar vein, P.D. Little (1984), D.A. Low (1963), Colins Leys (1975), E.A. Brett (1974), David Throup (1988) and J.G. Galaty (1980) indicate that in Kenya, encroachment on Masai pastoral lands dates to an early White-settler economy - when large tracts of grazing land were handed to the settlers. In neo-colonial Kenya, the land problem has remained unresolved. As a matter of fact, Michael M. Horowitz and Peter D. Little (1987) note that the loss of Masaigrazing land to state development schemes (including tourist parks), private farmers and ranchers, has made life increasingly hard for herders during drought.

With independence and the ensuing political dominance of agriculturalists, such as the Kikuyu, cultivators were permitted to settle in the higher rainfall, dry season pastoral areas. Further loss of pastoral lands in Kenya is attributed to the expansion of the tourist industry and national parks. Most of Kenya's tourist sector, its second largest earner of foreign exchange, focuses on wildlife resources, which are concentrated in the country's range areas. Indeed, two of the most important wild game areas in Kenya (Amboseli and Maasai Mara) are in Maasai regions. Both of these, particularly the swamp-grazing area of Amboseli, were significant grazing areas for Maasai. Recent legislation in Kenya, however, transformed Amboseli from a game reserve (which allows pastoral use of the area) into a national park that excludes pastoralists altogether. (75)

Therefore, deprived of swamp-grazing areas and traditional highland, 
pastoralists like the Masai of Kenya and Tanzania are compelled to concentrate their animals on already depleted lowland range areas.

Among the Dasanetch along the border of Kenya and Ethiopia, C.J. Carr (1977) indicates what the loss of grazing lands has meant: "In sum, the input of territorial restriction to the system has resulted in a self-perpetuating (or runaway) deterioration within the system, especially along the lines [of]: (1) environmental breakdown in the plains in the form of reduction of total plant cover, ... disruption of natural faunal assemblages, soil erosion, and (2) economic breakdown within the major production activity, ... increase in disease and death, and reduced milk yields ..." (226).

F.N. Ibrahim (1984) describes environmental degradation in terms of increasing marginalization of the peasants and pastoralists and high population growth in western Sudan:

\begin{abstract}
... the sound, traditional system of shifting cultivation turned into land misuse, and a chain of processes of deterioration of land productivity was begun: population increaseled to excessivecultivation, which, in turn, led to enhanced soil erosion and soil impoverishment. This resulted in the decrease of millet yields per hectare in the Sudan by half in the last 15 years. To make amends for this, the population, which is constantly increasing at an annual rate of 2.5 percent, had to increase the area cultivated with millet, from 392000 hectares in 1960 to 1055000 hectares in 1975. This expansion of cultivation meant a fresh wave of desertification.... The increasing persistence of the inhabitants in tilling the land despite lack of sufficient rainfall proves that they are not able to keep pace with the natural fluctuations any more. Instead of shifting southwards [i.e. away from pastoral zone] the peasants try to enlarge the area cultivated to be able to exist. This explanation of cultivation to counteract the decrease of rainfall works as a catalyst for the process of desertification. (110-18)
\end{abstract}

In pre-colonial Africa, people reacted to land and political pressure by migrating to open spaces. The creation and maintenance of colonial-national boundaries and its political institutions, population growth and land misuse created new challenges.

Environmental crises that are apparent in Africa are essentially the result of retrogressive political and economic decisions. The creation of game parks in societies where so many landless people exist, is a clear illustration of the nature of the state and the lopsided land policies in the region. Under the notion of comparative economic advantage, fertile lands are designated for production of export crops. The result is that peasants are forced to expand and overwork the land. Large-scale irrigation schemes, either for export production or hydroelectric power, not only lead to mass displacement and exodus of people, but also force peasants to claim and overwork delicate tracts of land. All these point to the nature of both the regional and global political economy.

\section{The Need for Change}

The first step should be a substantial, indeed, radical change in land-use policies in the region. Land distribution and tenure should address the fundamental needs of the sub-Saharan dwellers. Economic policies that favour export crops and agriculture at the expense of food crops and pastoralism need to be re-examined. For these changes to be explored, there is an urgent need to develop viable civil institutions that can effectively articulate and meet the socio-economic and political demands of the people. This will also require putting in place accountable democratic governments that respect human rights. Involuntary resettlement and the production of environmental refugees, who are often the victims of dam constructions and major projects funded by the World Bank and other financial institutions, must be avoided. Since environmental degradation is a significant threat to economic and social development, environmental concerns must become an important and integral part of economic and social policies on a national, regional and global scale. As far as Africa is concerned, environmental degradation is both a cause and an effect of poverty. It is around this issue of poverty and underdevelopment that the nature of neo-colonial states and the international economic system must be overhauled. The current politics of Structural Adjustment in sub-Saharan Africa, for example, have led only to more political, social, economic and environmental crises for the majority of the people. The way out is not more doses of the same politics of economic reform. The need for collective international actions is illustrated by the emergence of the global commons: the greenhouse effect, the deterioration of the ozone layer, the international movements of hazardous wastes and tropical deforestation. An understanding of climatic behavior that allows for early warning systems to operate adequately is urgently required for the region; and finally, the very word 'refugee,' given its meaning under international law, is too inadequate to accommodate environmental refugees. Therefore, there is urgent need to legally recognize environmental refugees so that they may be accorded necessary assistance through the UNHCR and other programs. 圆

\section{Selected Bibllography}

Adedeji, A. Dependency, Disequilibrium, Debt, and Destabilization (Addis Ababa: ECA, 1985).

Bates, R.H. Beyond the Miracle of the Market: The Political Economy of Agrarian Development in Kenya (Cambridge: Cambridge University Press, 1989).

Charney, J.G. "Dynamics of deserts and drought in the Sahel," Quarterly Journal of the Royal Meteorological Society, 101 (1975): 193-202.

Glantz, M.H.,(ed.), Drought and Hunger in Africa (London: Cambridge University Press, 1987).

Griffiths, J.F. Climates of Africa: World Survey of Climatology (Amsterdam: Elsevier 10, 1972).

Locfchie, M.F. "Political and economic origins of African hunger," Journal of Modern African Studies XIII, 4 (1975): 551-67.

Mamdani, M. "Disaster Prevention: Defining the Problems," Review of African Political Economy 33 (August 1985): 92-6.

Timberlake, L. African Crisis: The Causes, the Cures of Environmental Bankruptcy (London: Earthscan Publications, 1988). 